\title{
Interferon gamma replacement as salvage therapy in chronic pulmonary aspergillosis; effects on frequency of acute exacerbation and all-cause hospital admission.
} DOI:

10.1136/thoraxjnl-2019-213606

\section{Document Version \\ Accepted author manuscript}

Link to publication record in Manchester Research Explorer

Citation for published version (APA):

Monk, E. JM., Harris, C., Döffinger, R., Hayes, G., Denning, D. W., \& Kosmidis, C. (2020). Interferon gamma replacement as salvage therapy in chronic pulmonary aspergillosis; effects on frequency of acute exacerbation and all-cause hospital admission. Thorax. https://doi.org/10.1136/thoraxjnl-2019-213606

\section{Published in:}

Thorax

\section{Citing this paper}

Please note that where the full-text provided on Manchester Research Explorer is the Author Accepted Manuscript or Proof version this may differ from the final Published version. If citing, it is advised that you check and use the publisher's definitive version.

\section{General rights}

Copyright and moral rights for the publications made accessible in the Research Explorer are retained by the authors and/or other copyright owners and it is a condition of accessing publications that users recognise and abide by the legal requirements associated with these rights.

\section{Takedown policy}

If you believe that this document breaches copyright please refer to the University of Manchester's Takedown Procedures [http://man.ac.uk/04Y6Bo] or contact uml.scholarlycommunications@manchester.ac.uk providing relevant details, so we can investigate your claim.

\section{OPEN ACCESS}




\title{
Interferon gamma replacement as salvage therapy in chronic pulmonary aspergillosis: effects on frequency of acute exacerbation and all-cause hospital admission
}

\author{
Edward JM Monk (1) , ${ }^{1}$ Chris Harris, ${ }_{1,2}^{1,2}$ Rainer Döffinger, ${ }^{3}$ Gemma Hayes, $^{4}$ \\ David W Denning, ${ }^{1,2}$ Chris Kosmidis ${ }^{1,2}$
}

'National Aspergillosis Centre, Manchester University NHS Foundation Trust, Manchester, UK

${ }^{2}$ Division of Infection, Immunity and Respiratory Medicine,

Faculty of Biology, Medicine and Health, Manchester Academic

Health Science Centre, The University of Manchester, Manchester, UK

${ }^{3}$ Department of Clinical Biochemistry and Immunology, Addenbrooke's Hospital, Cambridge University Hospitals NHS Foundation Trust, Cambridge, UK

${ }^{4}$ Department of Respiratory Medicine, Derriford Hospital, University Hospitals Plymouth NHS Trust, Plymouth, UK

Correspondence to Dr Chris Kosmidis, National Aspergillosis Centre, Manchester University NHS Foundation Trust, Manchester M23 9LT, UK: chris.kosmidis@manchester. ac.uk

Received 20 May 2019 Revised 10 February 2020 Accepted 2 March 2020

Check for updates

(c) Author(s) (or their employer(s)) 2020. No commercial re-use. See rights and permissions. Published by BMJ.

To cite: Monk EJM, Harris C, Döffinger $\mathrm{R}$, et al. Thorax Epub ahead of print: [please include Day Month Year]. doi:10.1136/

thoraxinl-2019-213606

\section{ABSTRACT}

Chronic pulmonary aspergillosis (CPA) is often poorly responsive to antifungal treatment; secondary infections increase morbidity/mortality, particularly in progressive cases. Interferon gamma (IFN $\gamma$ ) has been implicated in not only Aspergillus control but also bacterial clearance. Clinical notes of patients with CPA treated with IFN $\gamma$ (2011-2018) were retrospectively hand-searched. In patients treated for $>12$ months $(n=20)$, the frequency of acute exacerbation reduced from 3.1 to 1.4 episodes/ year $(p=0.006)$ in the 12 months after treatment initiation compared with the 12 months before. A significant reduction in the frequency of hospital admissions/year was also observed (0.8 to $0.3, p=0.04)$. These findings support further prospective studies.

\section{BACKGROUND}

Chronic pulmonary aspergillosis (CPA) is characterised by persistent Aspergillus infection, usually complicating pre-existing lung diseases such as chronic obstructive pulmonary disease or bronchiectasis. Although patients are typically without immunocompromise, impaired production of interferon gamma (IFN $\gamma$ ) and/or interleukin 12 (IL-12) has been reported. ${ }^{1}$ IFN $\gamma$ prevents conidial germination, enhances alveolar macrophage killing capacity and manipulates Th1 CD4 cell/naturalkiller cell influx through chemokine signalling. ${ }^{2-4}$ As such, IFN $\gamma$ supplementation has been explored as a salvage therapy for severe CPA in patients with impaired IFN $\gamma$ production. ${ }^{5}{ }^{6}$ IFN $\gamma$ immunotherapy may have additional benefits as CPA is often complicated by recurrent bacterial superinfection; in chronic granulomatous disease, therapeutic IFN $\gamma$ reduces bacterial infections by up to $70 \%$.

This study reports the impact of subcutaneous IFN $\gamma$ supplementation on the frequency of acute exacerbation and all-cause hospital admission when administered as salvage therapy to patients with severe CPA, refractory to antifungals, and proven impairment of IFN $\gamma$ production.

\section{METHODS}

For this descriptive study, clinic letters and electronic hospital records were retrospectively handsearched for all patients prescribed IFN $\gamma$ salvage therapy for CPA at the National Aspergillosis Centre, Manchester, UK between January 2011 and September 2018 (46 patients). Subcutaneous
IFN $\gamma$ was self-administered at a dose of $50 \mu \mathrm{g}$ three times per week and prescribed according to clinical judgement when antifungal therapy appeared to be failing due to a combination of clinical, microbiological and radiological parameters in patients with impaired production of IFN $\gamma$ or IL-12 after in vitro cytokine induction.

For the induction of IFN $\gamma$, whole blood samples from patients and healthy controls were diluted 1:5 (Roswell Park Memorial Institute medium) into 96-well $\mathrm{F}$ plates (Corning) and activated with lipopolysaccharide (List Biochemicals, $1 \mu \mathrm{g} / \mathrm{mL}$ ) or phytohemagglutinin (Sigma, $10 \mu \mathrm{g} / \mathrm{mL}$ ), alone or in co-stimulation with IL-12 (ImmunoTools, $5 \mu \mathrm{g} / \mathrm{mL})$, and incubated at $37^{\circ} \mathrm{C} / 5 \% \mathrm{CO}_{2}$. For the induction of IL-12, whole blood was stimulated as above with lipopolysaccharide, alone or in combination with IFN $\gamma$ (Immukin, Boehringer, $2 \times 10^{4} \mathrm{IU} /$ $\mathrm{mL})$. Supernatants were taken after 24 hours and cytokine levels measured by standard ELISA (IFN $\gamma$ : PeliKine, Sanquin, the Netherlands) or multiplexed particle-based flow cytometry (IL-12: R+D Systems Fluorokinemap), according to the manufacturer's recommendations.

Patients were excluded from analysis if they started IFN $\gamma$ therapy within 12 months of the patient search $(n=5)$, were lost to follow-up $(n=4)$ or started IFN $\gamma$ prior to attending clinic $(n=1)$. The frequency of exacerbation, defined as an acute respiratory decline clinically requiring a course of antibiotics, and all-cause hospital admission were compared between the 12 months pre-IFN $\gamma /$ postIFN $\gamma$ initiation, stratified by duration of IFN $\gamma$ therapy (Wilcoxon matched-pairs signed-rank test). Incidence rates of death were compared on/off IFN $\gamma$ for the 36 patients meeting inclusion criteria, starting from the day of IFN $\gamma$ initiation through to September 2018 for a maximum follow-up of 60 months.

\section{RESULTS}

Of the 36 patients meeting the inclusion criteria, 20 received IFN $\gamma$ for $>12$ months, 8 stopped treatment due to side effects (all receiving IFN $\gamma$ for $<6$ months, mean duration: 2.5 months) and 8 patients died within 12 months of initiating treatment (mean IFN $\gamma$ duration: 4.6 months, mean survival: 7.5 months). The demographic characteristics of these 36 patients are shown in table 1 .

The death rate was statistically similar while 


\begin{tabular}{lc}
\hline Table 1 & Baseline characteristics of participants at INF $\gamma$ testing \\
\hline & Total (N=36) \\
\cline { 2 - 2 } Characteristic & $\mathrm{n}(\%)$ \\
\hline Age group (years) & $3(8)$ \\
\hline$<40$ & $1(3)$ \\
\hline $40-49$ & $19(53)$ \\
\hline $50-59$ & $10(28)$ \\
\hline $60-69$ & $3(8)$ \\
\hline$\geq 70$ & $56(51-65.5)^{*}$ \\
\hline Age, median (IQR) (years) & $18(50)^{*}$ \\
\hline Female sex & \\
\hline Smoking status & $8(22)$ \\
\hline Active & $9(25)$ \\
\hline Ex-smoker & $19(53)$ \\
\hline Never & \\
\hline Underlying pulmonary comorbidity $\dagger$ & $5(14)$ \\
\hline ABPA & $6(17)$ \\
\hline Asthma & $13(36)$ \\
\hline Bronchiectasis & $8(22)$ \\
\hline COPD & $5(14)$ \\
\hline Fibrosis (secondary to connective tissue disease) & $2(6)$ \\
\hline Malignancy & $6(17)$ \\
\hline NTM infection (active/previously treated) & $3(8)$ \\
\hline Non-COPD bullous lung disease & $6(17)$ \\
\hline Pneumothorax (previous) & $2(6)$ \\
\hline Sarcoidosis & $5(14)$ \\
\hline TB (previously treated) & \\
\hline & \\
\hline
\end{tabular}

*Demographics stratified by 12-month survival/exclusion: alive $(n=28)$, median age 56.5 [IQR: 50.5-65] years, sex 13/28 (46\%) women; dead $(n=8)$, median age 55.5 [IQR: 53-75] years, sex 5/8 (63\%) women.

tNot mutually exclusive: patients could have more than one underlying pulmonary comorbidity.

ABPA, allergic bronchopulmonary aspergillosis; COPD, chronic obstructive pulmonary disease; IFN $\gamma$, interferon gamma; NTM, non-tuberculous mycobacterium; $\mathrm{TB}$, tuberculosis.

receiving IFN $\gamma$ therapy $(0.16 /$ year $)$ compared with after stopping IFN $\gamma(0.12 /$ year $)(p=0.6)$, with a median follow-up of 33.5 months (IQR: 13-45 months). The 28 patients alive at 12 months were included in further analysis.

Twenty-two patients (79\%) were on concomitant antifungal therapy and 8 (29\%) were taking azithromycin for long term while receiving IFN $\gamma$. Two patients stopped antifungals as they transitioned to IFN $\gamma$ and azithromycin was started and stopped for one/two patients respectively in the 12 months preceding IFN $\gamma$ initiation. All remaining patients had the same on/off antifungal and azithromycin status throughout the 24 months of comparison (12 months pre-IFN $\gamma /$ post-IFN $\gamma$ initiation), though most patients on antifungals changed their regimen at some point due to adverse effects, azole resistance and/or clinical failure (figure 1).

In patients treated for $>12$ months $(n=20)$, there was a significantly lower number of acute exacerbations and hospital admissions in the year following IFN $\gamma$ initiation compared with the year prior (table 2). No significant changes were seen in patients treated with IFN $\gamma$ for $<6$ months for both outcomes $(n=8)$.
Patients receiving IFN $\gamma$ for $>12$ months (versus $<6$ months) were observed to have a greater difference between pre-IFN $\gamma /$ post-IFN $\gamma$ initiation frequencies of acute exacerbation and hospital admission, although not significantly so for exacerbation. Figure 1 demonstrates the number of acute exacerbations and hospital admissions in the 12 months pre-IFN $\gamma /$ post-IFN $\gamma$ therapy initiation on an individual basis.

Of the 10 patients who remained on the same antifungal treatment throughout the 24-month observation period, 8 received IFN $\gamma$ for $>12$ months (negative outcomes lower/equal/higher in $6 / 1 / 1$ patients) and 2 received IFN $\gamma$ for $<6$ months (negative outcomes lower/equal/higher in $0 / 1 / 1$ patients).

\section{DISCUSSION}

In this retrospective, descriptive study, patients with CPA refractory to antifungals alone appeared to have lower frequencies of acute exacerbation and all-cause hospital admission after the introduction of IFN $\gamma$ therapy. These effects were observed when IFN $\gamma$ was given for $>12$ months, but not for a duration of $<6$ months. Our observation is promising as acute exacerbations and hospital admissions are a substantial cause of morbidity and mortality in this patient population.

Almost all patients in our study had impaired IFN $\gamma$ production and those who did not have reduced levels of IL-12, a cytokine that stimulates IFN $\gamma$ production. It is not clear if this represents a primary immune defect or a consequence of chronic pulmonary disease or infection. The apparent beneficial effect of IFN $\gamma$ suggests that this is clinically relevant and could be mediated by its antibacterial, antiviral or antifungal action. Due to the chronicity of CPA and the number of patients treated, it was not possible to document a meaningful effect of IFN $\gamma$ on CPA's clinical course; there was no significant effect on Aspergillus serology, extent of CPA on imaging, microbiological eradication of Aspergillus or significant change in the profile of possible pathogenic organisms from sputum culture (data not shown). The frequency of adverse events and treatment discontinuation was high in this population of severely ill patients.

Long-term antifungals are the treatment of choice for CPA; most of our patients were on azoles. In addition, long-term macrolide treatment is often used for its anti-inflammatory properties and to prevent bacterial exacerbations in patients with chronic lung disease; several of our patients were taking azithromycin during the observation period. ${ }^{8}$ Admittedly, the concomitant use of antifungal and antibacterial treatment, with changes in regimen occurring in the majority of patients during the 24-month observation, may confound the results of this study. Only a minority of patients, however, had changes in their overall on/off treatment status during this time.

The patients included in this study were highly heterogeneous and treatment was individualised. Given this heterogeneity, using patients as their own comparator was considered to be the fairest way to present this retrospective data but is not without its flaws. Having failed to respond to antifungal therapy, they had poor prognosis from the offset. There is potential for introduction for bias if patients with a poorer physiological reserve responded less favourably to IFN $\gamma$ therapy, self-selecting into the $<6$-month treatment group. Patients lost to follow-up may also introduce further bias.

Patients who died within 12 months of therapy initiation were not included in the final analysis, arguably introducing bias by excluding the most physiologically vulnerable or patients with the most severe CPA. It is important to note, however, that all patients had declining prognostic indicators prior to starting 


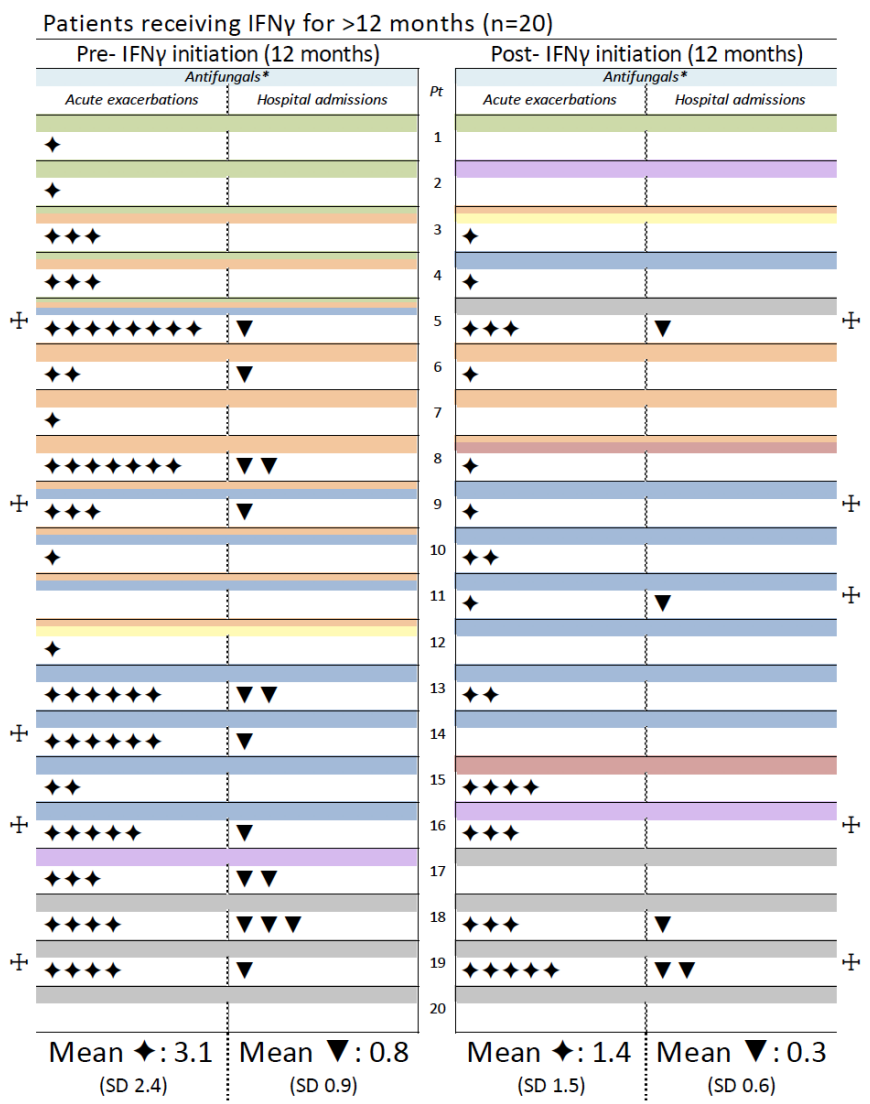

\begin{tabular}{|c|c|}
\hline Itraconazole & \\
\hline Voriconazole & \\
\hline Posaconazole & \\
\hline Isavuconazole & \\
\hline Amphotericin B & \\
\hline Micafungin & \\
\hline No antifungals & \\
\hline Azithromycin & $\Psi$ \\
\hline Acute exacerbation & \\
\hline Hospital admission & $\boldsymbol{V}$ \\
\hline
\end{tabular}

Patients receiving IFN for $<6$ months $(n=8)$
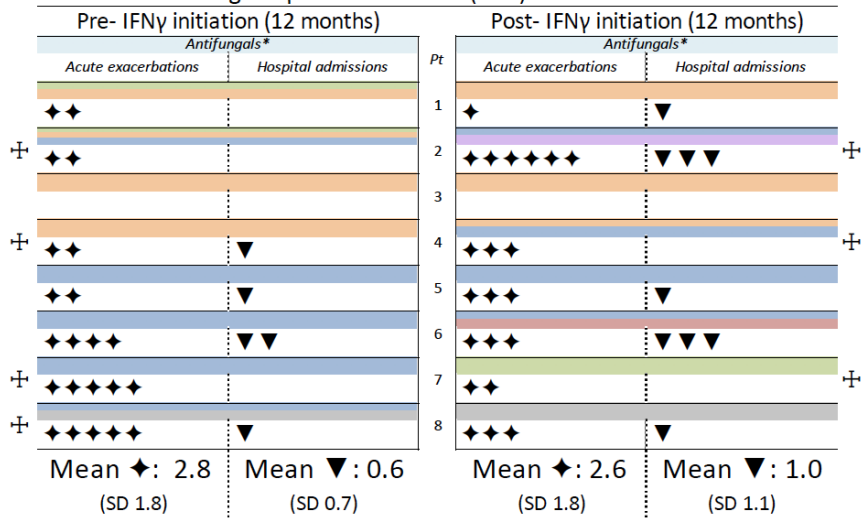
*Antifungals were not given simultaneously; depiction of multiple antifungals within the observation period pre- and/or post- IFNy initiation for any individual patient indicates a regimen switch/discontinuation (earliest regimen = top layer). For illustration
purposes, these are of equal width and not indicative of the proportion of the 12 months for which that regimen was received. Where a patient has a single solid line depicted, they received the corresponding antifungal for the duration of the 12 months.

Figure 1 Individual and mean frequencies of acute exacerbation and hospital admission in the 12 months pre-IFN $\gamma /$ post-IFN $\gamma$ initiation, with an illustration of concomitant antifungal/azithromycin treatment regimen, stratified by IFN $\gamma$ treatment duration. IFN $\gamma$, interferon gamma.

IFN $\gamma$. Inclusion of patients who died during the study period would itself have introduced its own bias; the methodology of a self-controlled case series was considered but deemed inappropriate due to death being a common outcome and the number of patients available. ${ }^{10}$ There was no evidence of IFN $\gamma$ therapy

Table 2 Number of acute exacerbations and hospital admissions pre-IFN $\gamma /$ post-IFN $\gamma$ initiation

\begin{tabular}{|c|c|c|c|}
\hline \multirow[b]{2}{*}{ Outcome and population } & \multicolumn{2}{|c|}{$\begin{array}{l}\text { Mean events over } 12 \text { months } \\
\text { (SD) }\end{array}$} & \multirow[b]{2}{*}{$P$ value } \\
\hline & $\begin{array}{l}\text { Pre-IFN } \gamma \\
\text { initiation }\end{array}$ & $\begin{array}{l}\text { Post-IFN } \gamma \\
\text { initiation }\end{array}$ & \\
\hline \multicolumn{4}{|c|}{ Acute exacerbations (clinically requiring antibiotics)* } \\
\hline \multicolumn{4}{|l|}{ IFN $\gamma$ duration } \\
\hline$>12$ months $(n=20)$ & $3.1(2.4)$ & $1.4(1.5)$ & 0.006 \\
\hline$<6$ months $(\mathrm{n}=8)$ & $2.8(1.8)$ & $2.6(1.8)$ & 0.7 \\
\hline \multicolumn{4}{|l|}{ Hospital admissions* } \\
\hline \multicolumn{4}{|l|}{ IFN $\gamma$ duration } \\
\hline$>12$ months $(n=20)$ & $0.8(0.9)$ & $0.3(0.6)$ & 0.04 \\
\hline$<6$ months $(\mathrm{n}=8)$ & $0.6(0.7)$ & $1.0(1.1)$ & 0.5 \\
\hline \multicolumn{4}{|c|}{ Comparison between $>12$-month and $<6$-month IFN $\gamma$ duration $\dagger$} \\
\hline Acute exacerbations & - & - & 0.06 \\
\hline Hospital admissions & - & - & 0.02 \\
\hline
\end{tabular}

*Wilcoxon matched-pairs signed-rank test.

tt-test.

IFN $\gamma$, interferon gamma. being detrimental to health; side effects leading to withdrawal were all mild and there was no difference in death rates between patients on/off IFN $\gamma$.

In summary, the frequencies of acute exacerbation and hospital admission were lower after the introduction of IFN $\gamma$ replacement therapy in patients with severe, refractory CPA. Prospective data are needed to further evaluate the role of IFN $\gamma$ as adjunctive therapy. In addition to control of fungal burden, IFN $\gamma$ may improve CPA morbidity/mortality by reducing the frequency and severity of bacterial or viral superinfection. These findings could apply to patients with other chronic lung diseases.

Acknowledgements The authors would like to thank patients at the National Aspergillus Centre, Manchester, UK for their continued engagement and support.

Contributors CK: conceived the project. RD: coordinated and interpreted immunodeficiency testing. CH and CK: performed the patient search. EJMM and CK: performed data collection; analysed and interpreted the data; drafted the manuscript. CH, RD, GH and DWD: critically revised the manuscript for intellectual content. All authors read and approved the final manuscript.

Funding The authors have not declared a specific grant for this research from any funding agency in the public, commercial or not-for-profit sectors.

Competing interests DWD and family hold Founder shares in F2G Ltd, a University of Manchester spin-out antifungal discovery company. He acts or has recently acted as a consultant to Scynexis, Cidara, Pulmatrix, Zambon, iCo Therapeutics, Roivant and Fujifilm. In the last 3 years, he has been paid for talks on behalf of Dynamiker, Hikma, Gilead, Merck, Mylan and Pfizer. He is a longstanding member of the Infectious Disease Society of America Aspergillosis Guidelines group, the European Society for Clinical Microbiology and Infectious Diseases Aspergillosis Guidelines group and the British Society for Medical Mycology Standards of Care committee.

Patient consent for publication Not required. 
Provenance and peer review Not commissioned; externally peer reviewed.

\section{ORCID iD}

Edward JM Monk http://orcid.org/0000-0001-9546-9650

\section{REFERENCES}

1 Döffinger $R$, Harris $C$, Lear $S$, et al. Reduced gamma interferon (gIFN) production in chronic pulmonary aspergillosis (CPA). Abstract 96, 5th advances against Aspergillus conference, 2012. Available: https://www.aspergillus.org.uk/content/reduced-gammainterferon-gifn-production-chronic-pulmonary-aspergillosis-cpa

2 Bouzani M, Ok M, McCormick A, et al. Human NK cells display important antifungal activity against Aspergillus fumigatus, which is directly mediated by IFN- $\gamma$ release. J Immunol 2011;187:1369-76.

3 Park SJ, Hughes MA, Burdick M, et al. Early NK cell-derived IFN-\{gamma\} is essential to host defense in neutropenic invasive aspergillosis. J Immunol 2009;182:4306-12.
4 Pak-Wittel MA, Yang L, Sojka DK, et al. Interferon- $\gamma$ mediates chemokine-dependent recruitment of natural killer cells during viral infection. Proc Natl Acad Sci U SA 2013;110:E50-9.

5 Denning DW, Cadranel J, Beigelman-Aubry C, et al. Chronic pulmonary aspergillosis: rationale and clinical guidelines for diagnosis and management. Eur Respir $J$ 2016:47:45-68.

6 Kosmidis C, Muldoon EG. Challenges in the management of chronic pulmonary aspergillosis. Med Mycol 2017;55:63-8.

7 Errante PR, Frazão JB, Condino-Neto A. The use of interferon-gamma therapy in chronic granulomatous disease. Recent Pat Antiinfect Drug Discov 2008;3:225-30.

8 Li W, Qin Z, Gao J, et al. Azithromycin or erythromycin? macrolides for non-cystic fibrosis bronchiectasis in adults: a systematic review and adjusted indirect treatment comparison. Chron Respir Dis 2019;16:1479972318790269.

9 Cui Y, Luo L, Li C, et al. Long-term macrolide treatment for the prevention of acute exacerbations in COPD: a systematic review and meta-analysis. Int I Chron Obstruct Pulmon Dis 2018;13:3813-29.

10 Petersen I, Douglas I, Whitaker H. Self controlled case series methods: an alternative to standard epidemiological study designs. BMJ 2016;354:i4515. 